\title{
THE IMPLEMENTATION AND MANAGEMENT OF E-LEARNING IN COMPANIES - THE STATE OF E-LEARNING IN HUNGARY BASED ON EMPIRICAL RESEARCH
}

UDC: 37.018.43:004.738.5(439)

Original Scientific Paper

\author{
József POÓR ${ }^{1,2}$, Péter SASVÁRI ${ }^{3}$, Zsigmond SZALAY ${ }^{2}$, István PETő ${ }^{2}$, \\ Norbert GYURIÁN ${ }^{1}$, Csilla Judit SUHAJDA $^{2}$, Ferenc ZSIGRI ${ }^{2}$ \\ ${ }^{1}$ J. Selye University, 94501 Komarno, Bratislavská cesta 3322, Slovakia \\ E-mail: poorjf@t-online.hu \\ ${ }^{2}$ Szent István University, Páter Károly utca 1, H-2100 Gödöllö, Hungary \\ ${ }^{3}$ Miskolc University, Egyetemváros, H-3515 Miskolc, Hungary
}

Paper received: 29.02.2020.; Paper accepted: 21.04.2020.

\begin{abstract}
In this article we attempt to review the basic theoretical concepts of e-learning as acknowledged in the relevant literature. We highlight the features of those improvements clearly visible in the field of e-learning, and we also deal with the accepted fact that modern e-learning systems offer much wider functionality than those of previous years. We have examined the status of e-learning in Hungary on a number of occasions, and, on the basis of those projects, we conducted our most recent empirical research in 2017. Our experiences show that e-learning has still neither managed to spread widely nor become a frequently used tool in the country. One of the root causes might be the lack of motivation. Although, we did observe some progress, in comparison with our earlier studies, this was modest. At the same point the results of our research show there is a correlation between company size (headcount and annual sales) and the use of e-learning.
\end{abstract}

Keywords: E-learning, Collective intelligence, Gamification, MOOC, WEB 2.0, Cloud, LMS, ACTIONS model, TAM model, Hungary.

\section{INTRODUCTION}

The advent of distance learning dates back to the ' 70 s in Hungary. This originally meant that students could study textbooks and handouts in their homes and, with the advance of technology (tape-recorders, video cassette players) the remote use of audio and video equipment also arrived. This form of education cannot entirely be a substitute for traditional methods, which are still necessary for learning some practical skills as well as for examinations. With the debut of distance learning, the efficiency of education has mostly risen to its present level. Following this, the conquest by the computer created new opportunities - i.e., e-learning, the essence of elearning being, quite simply, education supported by computers.

Computer Based Training (CBT) can be regarded as the first generation of e-learning - up to the mid-‘90s - which was hallmarked by the local use of information technology. In those years, distance learning was supplemented by teaching software packages equipped with off-line IT solutions (floppy disks, CDs). The advance of the Internet (from the $2^{\text {nd }}$ half of the ' $90 \mathrm{~s} \mathrm{p}$ to the early 2000s) produced the second generation of e-learning (WBT - WEB Based Training). With the mass application of the Internet and with the functional diversification of web-tools, the use of web-based learning appeared and became commonplace. The third generation of e-learning means the technological integration of learning, the application of Learning Management Systems (LMS) and Learning Content Management System (LCMS). In addition, the ever-increasing speed of internet access widens the variety of content that can be broadcast (images, audio, video), (Bates, \& Poole, 2003). With this, we have arrived at the present day when we stand at the gate of the new age of education. At this point it may be useful to 
offer a review of the relevant literature currently available.

Batalla, Rimbau, and Serradell (2014) explored the question: What kind of factors influence companies when they choose between using or not using e-learning? It is customary to suspect a relationship between e-learning usage and company size (a belief that the bigger the firm is, the more likely it is to employ e-learning) and to consider the average educational level of employees or the type of labour contract used.

It is supposed that indefinite (vs. definite) contracts also increase the likelihood of e-learning being used). In contrast, the above authors have found other determinants of e-learning use which may put this question in a completely different light. How intensively does a company use the novelties of IT in its daily operations? How innovative is the organization in the development of these technologies? The more progressive a company is in these areas, the more likely it is to use elearning, as well. These relationships have an important message which supports some of our observations on the e-learning market: e-learning is chiefly a toy of IT firms, and there is a chance that it will continue to be so. The above authors show that managers of e-learning projects must have a wide range of competencies.

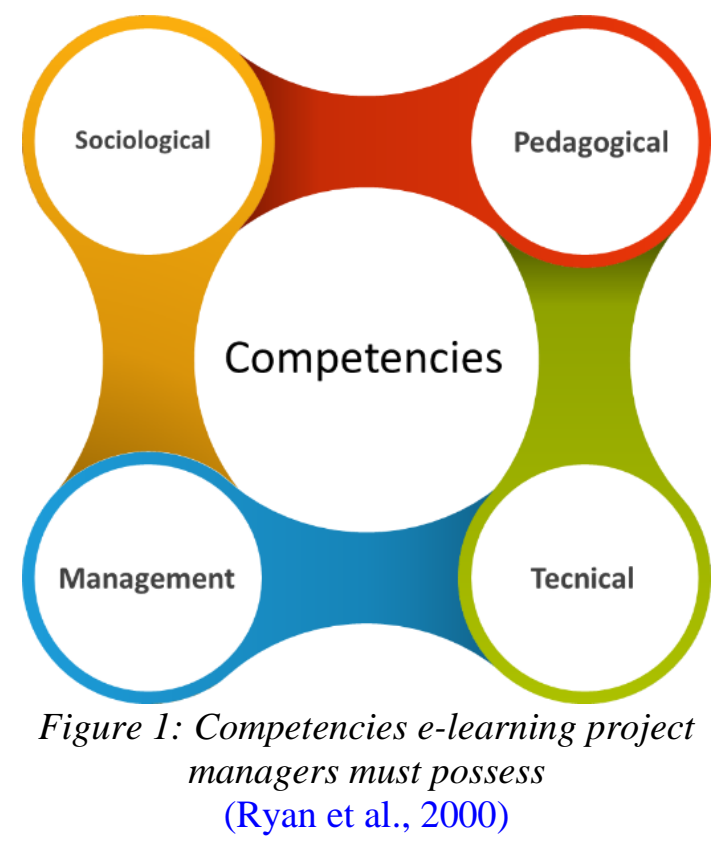

Beyond technical competencies, there are management, pedagogical and even sociological skills which these project managers must acquire (Figure 1).

Nagy (2016a) believes it imperative to clarify elearning concepts. From that perspective, he delineates four different approaches to e-learning. These are:

- technology,

- access,

- communication and interaction,

- teaching paradigm.

Naturally, the technological perspective regards elearning as a purely technological challenge: what kind of technological solutions are needed for the operation of e-learning? The second approach is from the perspective of access: what do we need do in order to provide access to the most people possible? The communication approach focuses on the role of communication among e-learning participants. Teaching paradigm approach - apart from the above, chiefly technical details investigates how human learning takes place. In other words, it looks at teaching as a fully-fledged profession in its own right. These approaches are unsurprisingly interrelated. Nagy deems that Learning Management Systems (LMS) does not solely support training, but it also traces it. In HE, Hungarian universities generally use the blended form of teaching (traditional methods $+\mathrm{e}-$ learning). Mainly large American universities can afford to apply e-learning exclusively. Those institutes are the flagships of Massive Open Online Courses (MOOC) (Karnouskos, 2017). They publish high quality online teaching content for free access by the general public, but participants must pay the university a considerable amount of money if they wish to receive official certificates of their studies.

The components of e-learning systems: all the participants, teaching content and the narrowly interpreted system itself (Poór et al., 2016). Poór refers to the role of mobile learning and he also opines that blended learning - a well-devised mixture of electronic and traditional methods - is a potentially good alternative to either purely electronic or traditional forms.

In our contribution we review related research and theories, examining why organizations choose to implement e-learning systems. In our research in Hungary our main hypothesis is that there is a 
correlation between company size (headcount and annual sales) and the use of e-learning.

\section{LITERATURE REVIEW}

\section{Advantages and disadvantages of e-learning use}

Nowadays it is very important that information and knowledge reach their destination as quickly and accurately as possible. One of the most common methods for this is the e-learning. Although countless research and experiences show its results, many companies do not consider it a useful tool yet.

Chang (2016) considers the advantages and also the decision criteria whether or not to introduce elearning into an organisation:

- smooth access to education,

- enhancing the quality of courses,

- cost reduction,

- enhanced cost efficiency (obviously related to the previous point), (Drozdova, \& Guseva, 2016).

He mentions in his study the Bates ACTIONS model as a collection of parameters indicating elearning quality:

- access,

- cost,

- teaching function,

- interactivity and user-friendliness,

- supporting organisational goals,

- novelty,

- speed (new courses are to be introduced into the system rapidly).

He browses the various ways in which human learning takes place and he proposes a pragmatic elearning function for each. He also touches on the differences between the needs of schools and industrial enterprises. The top priority issue and the key to the success of e-learning systems is still the trainee's desire to learn and the lovability of the system (Chang, 2016; Jeske, \& Stamov-Roßnagel, 2012; Zareie, \& Navimipour, 2016). Kaplan and Haenlein (2016) believe that student motivation is absolutely the key (Figure 2). This comprises:

- commitment (the given teaching content should be important for the student),

- challenges (overcoming certain types of problem motivates students),

- control (students should be kept under tight control),
- novelty (the actuality of teaching content is important for students),

- competition (tin-course competition among students improves motivation).

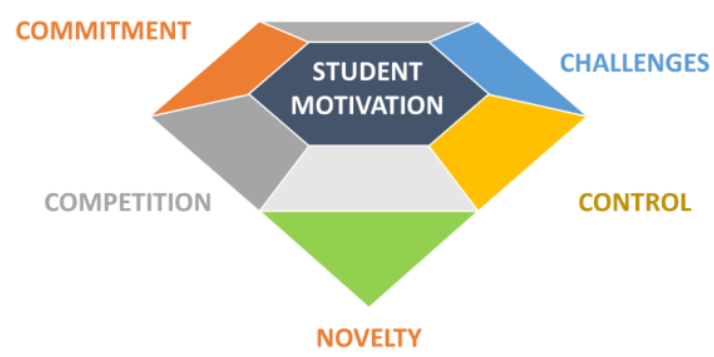

Figure 2: 5C model of student motivation (Kaplan, \& Haenlein, 2016)

Emilova (2016) identifies the factors with the biggest impact on the evolution of e-learning:

- economic factors (cost efficiency),

- technological background: new technologies created by the ceaseless development of IT (WEB 2.0, cloud),

- organisational background: similar training needs of employees working at different locations of global firms,

- sociological background: the requirements of lifelong learning.

E-learning is not meant for island operation. It can only work effectively as an e-learning ecosystem: it must comprise people, other living organisations and inanimate objects, their physical environment and the network of their interrelationships. As any system, this one also has elements (biotic and abiotic), limits and boundaries (physical and logical). The concept of lifelong learning is that learning should take place continuously, during every activity (whether it is described as studying or as anything else) which a person pursues. The essence of ubiquitous learning (Kotsiubynskyi, 2017; Manhasi, 2011) is also the fact that contemporary people are constantly linked to the internet, and so teaching content is continuously available to them. Therefore, learning can always be integrated into any activity. Since the teaching content is always available, people do not need time solely dedicated to studying. In this way, besides formal learning, informal learning also plays a key role in the acquisition of skills. In this manner, informal learning supplements and enhances formal learning. The evolution of mobile devices ensures mobile access to teaching content and so provides constant availability. WEB 2.0 technology promotes the collection and unification 
of information from multitudes of people (Palacios-Marqués et al., 2012).

Clearly, e-learning has its own drawbacks. Such an issue is the potential isolation of students from real human relationships or the uncertainty of the quality of teaching content. Cloud technology (Baris, 2015) is a noteworthy component of this virtual model, since it safeguards the collective management of data and resources in that it 'liquefies' the limits of user resources (In the cloud these are also collective and virtual). Therefore, these will always be available at the level which the user actually needs. This new achievement reaches beyond collective learning, since, with the help of collective learning, it facilitates the formation of new knowledge also. This is termed collective intelligence. E-learning will cause such revolutionary reforms of education which point much further than mere technicalities and will become a fundamental strategic issue for organisations, (Batalla-Busquets, \& MartínezArguielles, 2014; Emilova, 2016).

\section{The implementation of e-learning systems}

Yengin et al. (2011) presents us with a pragmatic approach to the implementation of e-learning systems. The very first question we need to resolve prior to the deployment of an e-learning system is; How can we devise such a system which students are willing to use? Key issues regarding this matter are:

- Encouraging the active role of students (Students should be encouraged to actively take part in lectures, rather than sitting silently, sleeping or live their social life via a smartphone.).

- Motivation (the lovability of the system).

- Adequate feedback (Without regular and honest feedback, students feel abandoned in the system).

The second question we need to address is: Which tool is the best for our purpose? The authors emphasise the potential of open source, free-ofcharge systems (Moodle, Sakai Project, LAMS) (Akimova et al., 2015; Dalkir, 2016; Imran, 2014; Tessier, \& Dalkir, 2016; Wang, 2018; Hayashi et al., 2020).

E-learning motivational strategies:
- retaining attention (such content that attracts attention, but does not unduly exhausts students),

- relevancy (any student should be allowed to choose content which interests him/her),

- self-confidence (students must be assured that completing the course will make them able to cope with the challenges ahead),

- satisfaction (unexpected rewards, gamification, recognition of good performance), (Yengin et al., 2011).

Kisielnicki and Sobolewska (2005) discuss the role of e-learning in corporate knowledge capital. Knowledge capital is an integral part of corporate assets and its high level gives the company a competitive edge. On the other hand, this asset depreciates in the same way as production machinery does. Therefore, it is imperative that companies maintain and improve their knowledge base. In consequence, training is not a one-off event in the life of organisations: they must accustom themselves to the culture of eternal training. They can choose among three ways: traditional training, e-learning and blended education. Whereas the costs of traditional training are almost constant, e-learning is completely different: it has high initial cost, but its cost function spectacularly drops over time (to a level well below that of traditional training). When decision-makers were asked about e-learning issues, they complained of high initial cost, elevated demand for dedicated resources at the start and the high ratio of trainees abandoning training (Kisielnicki, \& Sobolewska, 2010; Mbuva, 2014).

Tynjälä and Häkkinen (2005) point out that, in spite of schools - where the target population consists of very young adults - we have to deal with mature adults at their workplace. Hence, efficient workplace learning requires completely different methods. Meaning: e-learning is much more a pedagogical (andragogic) challenge than an informatical one (Yengin et al., 2010; Upadhyaya, \& Mallik 2013; Wan et al., 2012). While young people have no practical experience, adult employees do. In adult education all teaching has to be built on this (work and life) experience. Adults generally prefer training dealing with hands-on, practical problems in contrast to general, basic theoretical training designed for young students. Whereas daytime students have no other mandatory agenda apart from their studies, adult 
employees do - such as their jobs and possibly their families. Therefore a high level of flexibility is an important expectation in adult education (Tynjälä, \& Häkkinen, 2005). Typical e-learning failure causes:

- lack of fine-tuning,

- lack of cooperation and inadequate communication among participants,

- failure of training to focus properly on students.

E-learning is not a magic pill: it is not fit for curing acute organizational problems. On the contrary: these issues may undermine the success of elearning. E-learning must support a whole series of pedagogical necessities:

- support of cognitive processes (thinking),

- systemization of knowledge,

- externalization of thoughts,

- foundation (e.g. self-evaluation),

- creating professional skills,

- supporting collaborative processes,

- integrating acquired skills into daily practice (Esterhuyse et al., 2016).

\section{E-learning and Small \& Medium Sized Enterprises (SMEs)}

The capabilities and the needs of SMEs are remarkably dissimilar to those of big enterprises in general and on the training front also (Csillag et al., 2020; Mellett, \& O'Brien, 2014). While SMEs are pivotal players in the economy, their limited financial resources impede their keeping up with big enterprises in core areas of competitiveness. Continuous training is an indispensable tool for them, but they have neither a budget nor other resources. The adoption of economical external recourses could be of assistance:

- cooperation: an e-learning specialist transforms the education content of a traditional school and provides sit to the SME,

- an e-learning supplier connects with a traditional educational process and so creates a blended form,

- content syndicate: the contents of several standalone e-learning suppliers are merged on a common platform and provided to the SME,

- franchising: a competent provider creates a single brand, e-learning content, e-tutors and marketing concept and it franchises out this content to independent agents who provide it to the SME,
- subscription based systems: major content providers supply high quality material to clients in return for a subscription fee or free of charge,

- cooperation among SMEs: multiple SMEs create and share content with others,

- general market training: SME employees are sent to standard training courses with the aim of improving general skills (e.g. IT skills) available in bulk on the market.

\section{Application results}

A sound reason for e-learning is that it has proved itself to be a highly successful business even during the recession years (e.g. IBM managed to save US $\$ 200 \mathrm{~m}$ per annum by training its 95000 employees in an internal e-learning system and Dow Chemicals reported a cost reduction of $80 \%$ attributable to e-learning). The for-profit sector seemed to have high expectations of e-learning as an investment bearing fruiting profit terms even in the short run, and so the proliferation of this technology seemed certain. However, as it turned out, its direction and pace depend on many other factors.

The 'Coursera' project of Stanford University provides global courses by using state-of-the-art elearning techniques. Altogether 640000 students from 190 countries have taken part in some of their 43 courses, (Koller, 2012). Course content was created by the best tutors of the university, and practical experience confirms the many virtues of the system:

- All activities of the students can be continuously traced.

- This has facilitated the tailor-making of the courses (e.g. Incorrect answers received at examinations can be statistically analysed. The culmination of student misinterpretations per topic will show which parts of the content should be clarified or what the weakness of each student is).

- Every piece of teaching content can be repeated, relisted, reviewed as many times as needed.

- New forms of examination are available (e.g. problems requiring collaboration, programming challenges).

- Students have to actively communicate with the teaching content itself.

- Students may grade one another (peer grading).

- Students may communicate with one another in online forums. 
- Paperwork of tutors becomes simpler.

The system works on a milestone-based approach (mastery-based approach). There are many breakpoints which students cannot pass until they have proved their knowledge. With the MasteryBased Approach $98 \%$ of students rise to a higher level of knowledge and the in-group deviation drops by $90 \%$ in comparison with orthodox examining. Nevertheless, the most noteworthy potential of e-learning is that it makes learning available for people who could not even have dreamed of it earlier. Therefore, not only will the average knowledge level of employees rise for the benefit of all, but the odds in favour of discovering new talent - people who have the potential to achieve serious scientific breakthroughs for the good of mankind - will rise with it.

Jelonek et al. (2017) underline the complex role of e-learning in organizations. The operation of elearning must not be self-serving, and the relationship between e-learning and the achievement of corporate strategic goals must be tight and measurable. For this purpose, they put forward a balanced system of key performance indicators fine-tuned for e-learning. The indicators direct our attention to financial, customer and internal processes and to growth-development perspectives of corporate strategy. (Chen, 2008, 2010; Wang, 2011).

\section{The situation in Hungary}

Recent research (Ambrusné, 2013; Czakó, 2017; Poór et al., 2017) shows that e-learning is used sparingly in Hungary: most of those surveyed had not even heard of e-learning. The progress of elearning slowed down dramatically in 2016, and those who had not yet introduced e-learning did not plan to do so in the near future. There is no single dominant software program on the market and the proportions of free-of-charge and very expensive systems are very similar. This can be explained by the fact that the head offices of MNCs direct their local subsidiaries to use uniform software. As to the principal reasons for the introduction of e-learning, most respondents selected 'owner's decision' (local managers having no choice), and 'improvement of training efficiency' (Benta et al., 2015), 'opportunity to standardize training' and 'the simplification of paperwork related to training'. Whilst the main objective of e-learning is, by definition, the improvement of human resources, employee interests, desires and motivations play not even a tiny part in these decisions. The chief reasons for not using e-learning are: misfit with company culture, lack of skills, no money, no staff and lacking training content, (Poór et al., 2017).

One of the numerous prerequisites of e-learning deployment is the fitness of the organization. This equally means the preparedness of the organization, the management, the technology, the staff and the HR colleagues.

The Hungarian private sector mostly uses elearning for the following tasks:

- induction of newcomers,

- in the case of high fluctuation levels, for the training of standardized jobs (e.g. semi-skilled operators),

- regularly repeated training (e.g. fire protection, workers' protection).

In addition, there are examples of companies who - within the framework of their Company Social Responsibility (CSR) activities - offer online training for female employees on maternity leave (Csapóné, \& Tóth, 2017).

In the Hungarian public sector, e-learning is used for the training of a series of identical jobs in which large work-forces are employed nationwide (Nagy, 2016b). Taking part in such training is often prescribed by law and employers are also expected to identify training needs. These events can be attendance-based (training courses or conferences) or e-learning-based (built on presentations and videos - for more details see Orbán-Balkányi (2015) - or animations), blended learning (e-learning content supplemented by faceto-face consultations) (Belényesi, \& Dobos, 2015). Paksi-Petró (2017) claim that the above forms are extremely demanding and costly for leaders in the public sector, and so self-coaching may be a better alternative in their case.

\section{THE EMPIRICAL RESEARCH}

With the support of AR Tudásmenedzsment Kft., the Management and HR Research Centre of Szent István University, the National University of Public Service and the Budapest Chamber of Commerce and Industry we undertook research in 2017 with the purpose of forming an opinion about the use of e-learning and its practical implications in Hungarian companies and institutes. We carried 
out a review of relevant literature in international scientific databases relating to the subject, and the literature review presented in our article strives to be the foundation for the theoretical background of our empirical research - in which 374 Hungarian organisations (firms and public institutions) - as well as for our comprehensive publication - to be published in Hungarian and in English languages.

Hypotheses: There is a correlation between company size (headcount and annual sales) and the use of e-learning. Whilst smaller companies can resort to the opportunities of verbal communication, this cannot work in large firms.

1. Foreign-owned companies are more likely to use e-learning than are domestically-owned ones.

2. Companies specialised in education are more likely to use e-learning than any other firm.

3. The main target groups for e-learning are white collar employees. The technological level of the training of these is higher than to that of blue collar workers.

\section{The sample}

Out of the firms we approached in different locations of the country, 375 responded. Two thirds of the respondents are from the private sector, with over one quarter from the public sector. Some $60 \%$ of the respondents are domestically-owned whilst $36 \%$ are foreignowned. Over $75 \%$ have headquarters in Budapest, whilst $12 \%$ are in major provincial cities, the remaining $10 \%$ being in other locations.

Respondents belong to 19 different sectors, the most frequent being public service and social security service $(10 \%)$, wholesale trade and retail trade (both $8 \%$ ), financial sector and construction industry (both 6\%).

Nearly one-third of the respondents use e-learning for training purposes and have done so for 7 years on average.
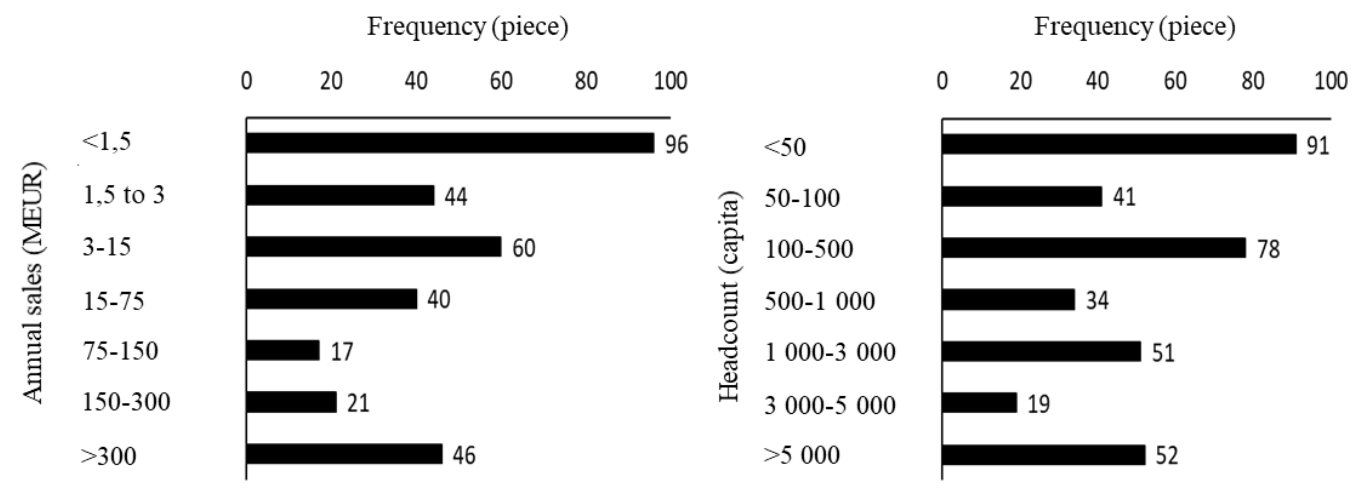

Figure3: The attributes of respondent organisations (sales and headcount)

\section{Statistical analysis and results}

A cross-tabular analysis shows a significant correlation between company size (measured by annual sales and headcount) and their use of elearning. Pearson $\chi^{2}$ is 54 for sales-e-learning use pair and 101 for headcount-e-learning use pair. Kendall's tau proves the mediocre strength of the relationship for both sales and headcount $(0.443$ and 0.587 , respectively). Gamma gives us similarly high values ( 0.525 and 0.669 , respectively).

Bearing this in mind, the conclusions are: a mere $25 \%$ of extremely small and only $18 \%$ of low headcount companies use e-learning. With the increase of sales and headcount, e-learning use gradually rises, also (in this case Pearson $\chi^{2}$ is 13.7). 

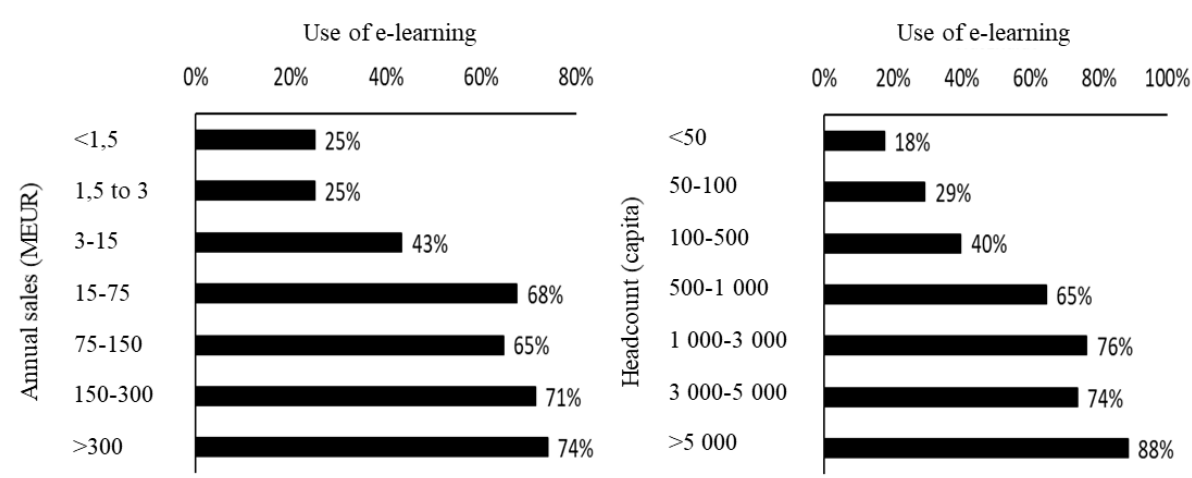

Figure 4: The size of respondents and their e-learning use

The likelihood of use is not exclusively size-driven as ownership also influences it. Statistical analysis shows a significant relationship between the type of owner and e-learning use, although, this correlation is significantly weaker (Phi and Cramer $\mathrm{V}=0.191)$.

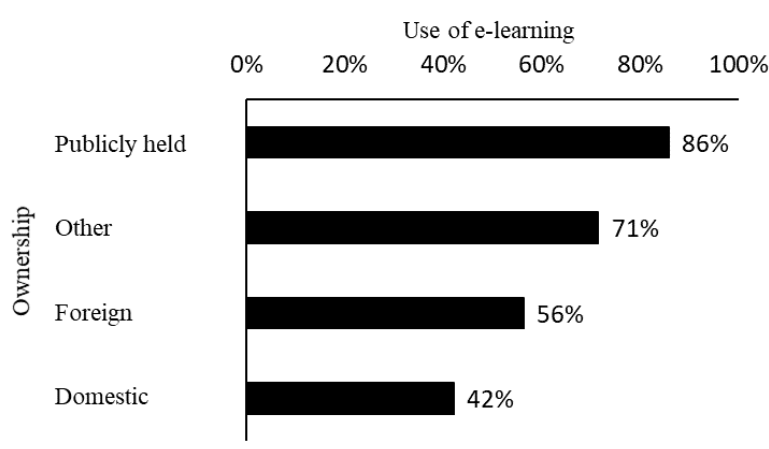

Figure5: Ownership and the use of e-learning

Our research shows that e-learning usage is lowest in domestic companies (42\%) and highest in public limited companies $(86 \%)$.

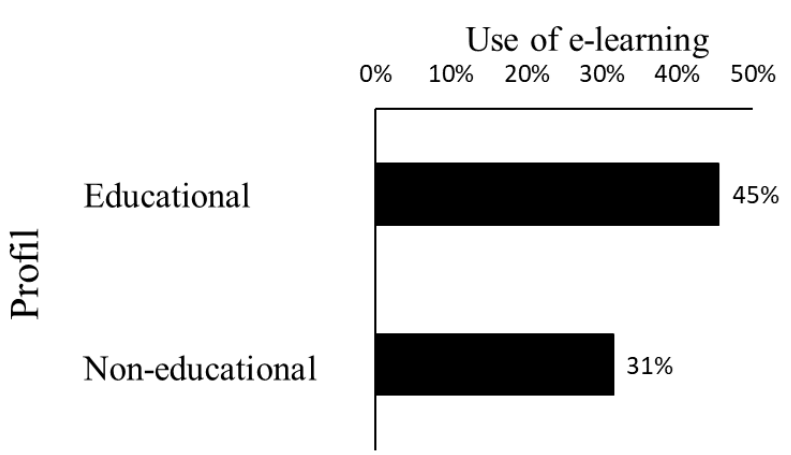

Figure 6: Specialisation and the use of e-learning

We also hypothesized that firms specialized in education are more likely to use e-learning. There are 32 educational institutions in our sample. Cross-tabular analysis, however, proves no significant correlation between educational specialization and e-learning use (Pearson $\chi^{2}=2.5$ at sig $=0.112$ ). In other words: the higher ratio (45\%) measured in educational organisations than in other organisations $(31 \%)$ is random.

Blue collars

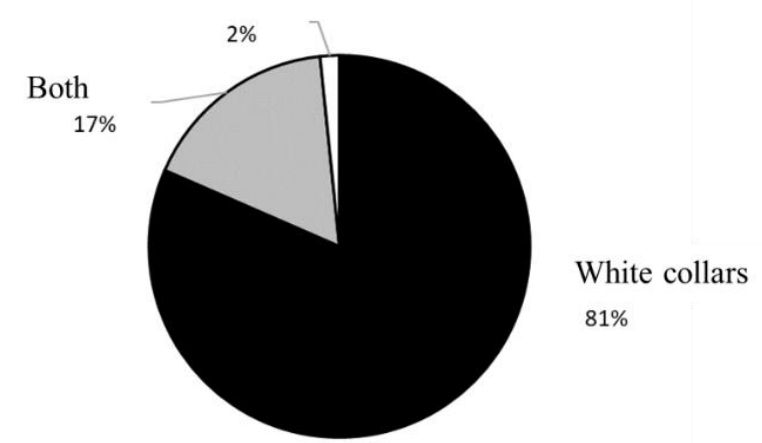

Figure7: Target groups of online training

E-learning is suitable for white-collar and bluecollar workers, alike. Our research shows that over $80 \%$ of responding organisations use e-learning with the main purpose of training the white-collar sector, whilst a mere $3 \%$ use e-learning with a focus on the blue-collar.

\section{Discussion}

E-learning is a potentially most powerful tool suitable to boost a revolutionary breakthrough in education. Distance learning freed the bottleneck imposed by time and space limitations - in trainer capacity inherent in orthodox paradigms. The development of computers and the internet facilitated digitalization and worldwide networks. This technological advance has opened opportunities never seen before for education. Besides making education available to the masses, it also supports so high a level of collaboration among them as to dwarf geographical distance. Elearning facilitates the organisation of training and the administration and tracking of student activities. E-learning is also good for stimulating a 
number of different human senses, and so it can enhance learning efficiency.

Nevertheless, e-learning has so far failed to achieve the expected breakthrough in education. Corporate enthusiasm was never strong enough, and, in addition, it has even declined further in the meantime.

Whilst IT professionals enthusiastically keep developing new and wonderful functionalities in elearning systems, the appetite of corporate decision-makers is at a low level. Of course, there are many causes for this reluctance. At SMEs who form the great majority of companies - there is no money for training, since their financial reach is much shorter than that of multinationals. SMEs often have to fight daily battles for mere overnight survival. As much as they lack sufficient funding, they also lack proficiency. This is a trap for SMEs: they cannot keep up with major companies since they cannot afford to improve their knowledge capital. Consequently, their handicap in competitiveness is likely to endure.

The implementation of e-learning systems carries an abundant supply of potential problems. No-one likes an e-learning system if it is badly implemented and poorly operated- and, unfortunately, such systems are not uncommon. Typically, besides IT and HR staff, only Quality Control departments are passionate about such systems - since e-learning often relieves them of some part of their administrative burden. At the same time, studies testify that this limited enthusiasm is insufficient for total success as the elearning market currently seems to be static. Decision-makers do not seem to believe that elearning may truly benefit them. A further problem is that, while e-learning systems are principally regarded as IT challenges, in reality such a project is much more labyrinthine and requires multidisciplinary collaboration. Teaching is a fully-fledged profession with its own methodology, and e-learning demands pedagogical skills, also. For-profit enterprises like to engage only in activities that measurably generate certain profits preferably immediate cash. This would require the involvement of some form of auditing or controlling, and knowledge management methodology would also be needed for the systematisation of knowledge. Since learning implies constant change, then change management skills would be necessary too. Whilst 'learning organisation' and 'knowledge based economy' have become fashionable slogans, too often they are no more than empty words. A large number of organisations are still unable to operate efficient learning processes and company training is often carried out superficially. Many Western MNCs use Eastern Europe as a quasi-assembly line (simple shop floors, stripped of any complex functions), and this kind of activity in fact does not require such a high level of knowledge capital at local factories - as much more elaborate tasks do at their Western headquarters, where THE lion's share of research and development, strategic planning or concern management are performed. Hence, we are compelled to question whether serious knowledge is indeed necessary for these somewhat simplified factories. Excessive cost cutting pressure is also hostile to learning, since the benefits of knowledge acquisition generally appear only in the long term, and so it is doubtful whether some companies can afford to spend money on such activity. SMEs - by and large - cannot.

Organisational learning is, above all, a cultural concern, and cultural change invariably takes time. Most company cultures do not support organizational learning and, consequently, do not promote e-learning either. Any system without sound organizational support is doomed to failure.

Compared with the great potential of e-learning, we must acknowledge that it is currently unsuccessful. The root causes go deep:

The general considerations in the e-learning concept:

- We should be able to calculate exactly the payback of e-learning if we want to convince decision-makers. This calculation would be best performed through the impact of e-learning on the productivity of direct labour.

- E-learning is predominantly looked upon as an IT issue. In truth, it is much more of a pedagogical challenge.

- Complex problems of organisations - in relation to e-learning - are neglected.

The misfit of organisations:

- leaders are uninterested,

- organisations resist change,

- short-termism (often, the only thing that really matters is the annual business plan),

- bottlenecks in financing and resources,

- training function is totally missing in the organisation, 
- there is no teaching content available,

- in some cases employees are treated disrespectfully by employers.

\section{CONCLUSIONS AND FURTHER PLANS}

Seeking solutions to the problems of e-learning does not seem to be advisable in the field of further developing system functionality - since the rejection of e-learning is not related to a lack of functionality. Organisations turn down e-learning because they cannot see that they could benefit from e-learning or they see themselves unsuitable. We may, therefore, find the solution in dealing with the restraining factors of e-learning use:

- an appropriate system must be implemented with maximum care;

- the system must clearly show high operational quality;

- the organisation should be receptive.

These three criteria must all be evenly met for elearning to thrive. The most critical issue might be with receptiveness, since most companies seem to be incapable of handling this issue alone. Consultants should assist them with this issue if they aspire to sell their systems and their counselling. Unfortunately, even most of the literature we found is concerned only with the technicalities of e-learning. In other words, they seek solutions where no problems exist. We found hardly any publications dealing with organizational development, change management or the strategic perspectives of e-learning. Answering the 'How' and 'By what' questions is heavily overplayed, whilst 'Why' or 'Why not' are ignored. Why would organisations operate e-learning? As long as we do not address these questions, we cannot find adequate solutions, and so e-learning will stay put.

\section{REFERENCES}

Akimova, O., Bobyreva, N., Palutina, O., \& Pomortseva, N. (2015). Distance Language Education. Procedia-Social and Behavioral Sciences, 199, 348-356.

Ambrusné-Somogyi K. (2013). E-learning in Higher Education - Educational Opportunities in Adult Education (In Hungarian). Acta Carolus Robertus 3(1), 155-161.

Baris, M. F. (2015). Future of E-Learning: Perspective of European Teachers. Eurasia Journal of Mathematics, Science \& Technology Education, 11(2), 421-429.
Batalla, J. M., Rimbau, E., \& Serradell, E. (2014). Elearning in Economics and Business. Universities and Knowledge Society Journal, 11(2), 3-11.

Batalla-Busquets, J. M., \& Martínez-Argüelles, M. J. (2014). Determining factors in online training in companies. The International Journal of Management Education, 12(2), 68-79.

Bates, A. W., \& Poole, G. (2003). Effective Teaching with Technology in Higher Education: Foundations for Success. San Francisco: Jossey-Bass

Belényesi, E., \& Dobos, Á. (2015). Approach or distance? Trends in continuing education in the Hungarian public administration and the US Federal Public Service. (In Hungarian) New Hungarian Public Managent (Új Magyar Közigazgatás), 8(2), 32-44.

Benta, D., Bologa, G., Dzitac, S., \& Dzitac, I. (2015). University level learning and teaching via e-learning platforms. Procedia Computer Science, 55, 13661373.

Chang, V. (2016). Review and discussion: E-learning for academia and industry. International Journal of Information Management, 36(3), 476-485.

Chen, E. T. (2008). Successful e-learning in corporations. Communications of the IIMA, 8(2), 5.

Chen, H. J. (2010). Linking employees'e-learning system use to their overall job outcomes: An empirical study based on the IS success model. Computers \& Education, 55(4), 1628-1639.

Csapóné-Riskó, T., \& Tóth, E. (2017).Corporate Responsibility: Internal CSR programs for employees (In Hungarian). Current social and economic processes (Jelenkoritársadalmi és gazdaságifolyamatok), 12(4), 207-191.

Csillag, S., Csizmadia, P., Hidegh, A. L., \& Szászvári, K. (2020). A kicsiszép? Tanulás és fejlődés a kisvállalkozásokban (Is small beautiful? Learning and development at small enterprises).

Vezetéstudomány - Budapest Management Review, 51(1), 2-15.

Czakó, K. (2017). Higher Education Institutions and Business Development. (In Hungarian) Civil Review (Polgári Szemle), 13(1-3), 133-147.

Drozdova, A.A., \& Guseva, A.I. (2016). Modern Technologies of E-learning and Its Evaluation of Efficiency. Procedia - Social and Behavioral Sciences, 237, 1032 - 1038.

Emilova, P. (2016). E-Learning In Business Organisations-New Concepts, Technologies And Models. Бизнес управление, 26(3), 21-44.

Esterhuyse, M., Scholtz, B. \& Venter, D. (2016). Intention to Use and Satisfaction of e-Learning for Training in the Corporate Context. Interdisciplinary Journal of Information, Knowledge, and Management, 11, 347-365.

Hayashi, A., Chen, C., Ryan, T., \& Wu, J. (2020). The Role of Social Presence and Moderating Role of Computer Self Efficacy in Predicting the Continuance Usage of E-Learning Systems. Journal of Information Systems Education, 15(2), 5. 
Jelonek, D., Dunay, A., \& Illés, Cs. B. (2017). Academic E-learning Management with E-learning Scorecard. Polish Journal of Management Studies, 16(2), 122-132.

Imran, S.M., (2014). E-learning Strategies for Imparting LIS Education in India: A Pragmatic Perspective of Faculty Members. Trends in Information Management, 10(1), 23-38.

Jeske, D., \& Stamov-Roßnagel, C. (2012). Success by inclusion: "Age fair" e-learning practices. Organizational Dynamics, 41(4), 302-307.

Kaplan, A. M., \& Haenlein, M. (2016). Higher education and the digital revolution: About MOOCs, SPOCs, social media, and the Cookie Monster. Business Horizons, 59(4), 441-450.

Karnouskos, S. (2017). Massive Open Online Courses (MOOCs) as an Enabler for Competent Employees and Innovation in Industry. Computers in Industry, 91, 1-10.

Kisielnicki, J., \& Sobolewska, O. (2010). E-learning as a Strategy of Acquiring a Company's Intellectual Capital. Interdisciplinary Journal of E-Learning and Learning Objects, 6(1), 153-174.

Koller, D. (Producer). (2012, 20.08.2018). What we're learning from online education. Retrieved from https://www.youtube.com/watch?v=U6FvJ6jMGHU \&list=PLeW9mwgoe3NsDt1opuSPFGwcx5D363oo\&index $=2$

Kotsiubynskyi, M. (2017). Blended Learning and Innovative Technologies in Training of the Future Specialists in the Foreign Higher Education Institutions. Comparative Professional Pedagogy, 7(1), 8-13.

Manhasi, P.S. (2011). Role of Online Education in Building Brand Image of Educational Institutions. Jammu, Tawi, India: University of Jammu.

Mbuva, J. M. (2014). Online education: Progress and prospects. Journal of Business and Educational Leadership, 5(1), 91.

Mellett, S., \& O'Brien, E. (2014). Irish SMEs and e- learning implementation: The strategic innovative approach. British Journal of Educational Technology, 45(6), 1001-1013.

Nagy, V. (2016a). E-learning ABC. Vezetéstudomány, 47(12), 6-15.

Nagy, V. (2016b). The complexity of e-learning implementation - an example of the Hungarian market (In Hungarian). Tavaszi Szél, 400-409.

Orbán, Zs-Balkányi P. (2015). Development of elearning curricula in public administration (In Hungarian). Pro publico bono - Magyar közigazgatás, (4), 100-111.

Paksi-Petró, Cs. (2017).Educational-methodological novelties in administrative leadership development (In Hungarian). Political Science Workshops(Államtudományi Mühelytanulmányok) (13), 1-18.
Palacios-Marques, D., Cortes-Grao, R., \& Carral, C. L. (2013). Outstanding knowledge competences and web 2.0 practices for developing successful elearning project management. International Journal of Project Management, 31(1), 14-21.

Poór, J., Szalay, Z., Pető , I., Zsigri, F., \& Sasvári, P. (2017). E-Learning in Management and Renewal of Organizational Knowledge - an Empirical Study (In Hungarian). Paper presented at the Conference on Management of Hungarian Academy of Sciences, Budapest.

Poór, J., Sasvári, P., Nesterowicz, K., Monda, E., Fawzi, M., Eldurssi, \& Nikolic, M. (2016). E-learning in Management - Focus on Hungary, Serbia and Slovakia. Journal of Management And Financial Sciences, 9(23), 93-122.

Ryan, S., Scott, B., Freeman, H., \& Patel, D. (2000). The Virtual University: The Internet and Resourcebased Learning. New York and London: Routledge.

Tessier, D., \& Dalkir, K. (2016). Implementing Moodle for e-learning for a successful knowledge management strategy. Knowledge Management \& ELearning: An International Journal, 8(3), 414-429.

Tynjälä, P., \& Häkkinen, P.(2005). E-learning at work: theoretical underpinnings and pedagogical challenges. The Journal of Workplace Learning, 17(5/6), 318-336.

Upadhyaya, K. T., \& Mallik, D. (2013). E-learning as a socio-technical system: An insight into factors influencing its effectiveness. Business Perspectives and Research, 2(1), 1-12.

Wan, Z., Compeau, D., \& Haggerty, N. (2012). The effects of self-regulated learning processes on elearning outcomes in organizational settings. Journal of Management Information Systems, 29(1), 307-340.

Wang, M. (2011). Integrating organizational, social, and individual perspectives in Web 2.0-based workplace e-learning. Information Systems Frontiers, 13(2), 191-205.

Wang, M. (2018). E-Learning in the Workplace. Switzerland: Springer International Publishing AG

Zareie, B., \& Navimipour, N. J. (2016). The effect of electronic learning systems on the employee's commitment. The International Journal of Management Education, 14(2), 167-175.

Yengin, İ., Karahoca, D., Karahoca, A., \& Uzunboylu, H. (2010). Re-thinking virtual universities. Procedia-Social and Behavioral Sciences, 2(2), 5769-5774.

Yengin, I., Karahoca, A., \& Karahoca, D. (2011). Elearning success model for instructors' satisfactions in perspective of interaction and usability outcomes. Procedia Computer Science, 3, 1396-1403. 


\title{
IMPLEMENTACIJA I UPRAVLJANJE E-UČENJEM U PREDUZEĆIMA - STANJE E-UČENJA U MAĐARSKOJ BAZIRANO NA EMPIRIJSKOM ISTRAŽIVANJU
}

\begin{abstract}
U ovom radu analiziraju se osnovni teorijski koncepti e-učenja iz relevantne literature. U istraživanju izdvajamo karakteristike poboljšanja prisutnih u domenu e-učenja. Takođe se bavimo prihvaćenom činjenicom da savremeni sistemi e-učenja nude mnogo širu funkcionalnost naspram sistema koji su bili aktuelni prethodnih godina. Više puta smo istraživali stanje primene e-učenja u Mađarskoj, i na osnovu tih projekata, sproveli smo (najskorije) empirijsko istraživanje u 2017. godini. Naša iskustva ukazuju da e-učenje još uvek nema široku primenu niti se često koristi kao alat u državi. Jedan od glavnih razloga može biti nedostatak motivacije. Iako je primećen određen napredak, naspram prethodnih istraživanja, ovaj napredak je skroman. Istovremeno, rezultati našeg istraživanja ukazuju da postoji korelacija između veličine preduzeća (broj zaposlenih i godišnja prodaja) i primene e-učenja.
\end{abstract}

Ključne reči: E-učenje, Kolektivna inteligencija, Gamifikacija, MOOC, WEB 2.0, Cloud, LMS, Akcioni model, TAM model, Mađarska. 